\title{
Nitrogen (N) and Potassium (K) Supplementation to Improve Salt Tolerance in Brassica (Brassica juncea, cv: Agati sarheen)
}

\author{
M. U. Shirazi ${ }^{1, *}$, M. T. Rajput ${ }^{2}$, M. A. Khan ${ }^{1}$, R. U. Ansari ${ }^{3}$ \\ ${ }^{1}$ Nuclear Institute of Agriculture, Tando Jam, Pakistan \\ ${ }^{2}$ University of Sindh, Jamshoro, Pakistan \\ ${ }^{3}$ Institute of Sustainable Halophyte, University of Karachi, Karachi, Pakistan
}

Copyright $\bigcirc 2018$ by authors, all rights reserved. Authors agree that this article remains permanently open access under the terms of the Creative Commons Attribution License 4.0 International License

\begin{abstract}
To observe the mitigating effects of nitrogen and potassium under salinity on Brassica juncea (cv. Agati sarheen), $\mathrm{N}$ and $\mathrm{K}$ was supplemented at different stages of growth. The studies were conducted under control condition (gravel culture). Salinity (12 dS/m) was imposed by $\mathrm{NaCl}$ salt after three weeks of germination through irrigation (1/4 ${ }^{\text {th }}$ Hoagland solution). Nitrogen and Potassium was applied exogenously in the form of $\mathrm{KNO}_{3}$ @ (T1.30mM and $\mathrm{T} 260 \mathrm{mM})$ at vegetative and flowering stage. There was decrease in growth and yield under salinity. However; the relative reduction in plant height, slique length, grain wt/ 5 slique and grain yield/ 15 plants was comparatively low due foliar application of $\mathrm{N}$ and $\mathrm{K}$ as compared to non applicated plants. The overall accumulation of organic solutes (proline and glycine betaine) was significantly high under salinity. The response of $\mathrm{N}$ and $\mathrm{K}$ application was almost nil in case of proline accumulation. On the other hand application of $\mathrm{KNO}_{3} @$ $30 \mathrm{mM}$ showed increased accumulation of glycine betaine. The uptake of $\mathrm{Na}$ under salinity was less in plant having $\mathrm{KNO}_{3}$ application@30mM (T1). Potassium content under saline condition was high in $\mathrm{KNO}_{3} @ 60 \mathrm{mM}$ (i.e. T2 treatment), resulting in high $\mathrm{K} / \mathrm{Na}$ ratio. The application of $\mathrm{KNO}_{3}$ also found to increase in nitrogen content in brassica. It is therefore concluded that better performance of brassica genotype under salinity might be due to low $\mathrm{Na}$ uptake and high $\mathrm{K} / \mathrm{Na}$ ratio especially under $\mathrm{T} 1$ treatment (i.e $\mathrm{KNO}_{3}$ (a) 30mM).
\end{abstract}

Keywords Salinity, Brassica, Nitrogen, Potassium Supplementation

\section{Introduction}

Salinity is a major constrain in arid and semiarid areas of the world. About 6.8 million hectares, salt affected soils occupy in Pakistan (Khan,[1], Khan et al., [2], Shirazi, et al [3]), which is about $30 \%$ of the total cultivated area of Pakistan (Govt of Pakistans, [4]).

The ability of plant to grow and complete its life cycle on saline soils is regarded as salt tolerance, which vary among the plant type and within genotypes of same species. Rapeseed (B. napus L.) and mustard (B. juncea (L.) Czern. $\&$ Coss.) are the common brassica oil-seed crops grown for commercial purposes. Brassica species ranks as third among oilseed crops and are an important source of edible oil. It is categorized as medium salt tolerant crop (Maas and Hoffman, [5]. The salt tolerance among the brassica species varies due to their physiological response e.g. electrolyte leakage, proline accumulation and the K/Na ratio (Puppala et al., [6]; Mer et al., [7]; Bybordi, [8]; Tunuturk et al.,[9]; Zamani et al., [10]. It is reported that though the brassica species have high threshold values but the yield decrease is very high above the threshold values than most other crops in the tolerant category (Maas, [11] Ashraf and McNilly [12]).

It is therefore, necessary to adopt suitable strategies for the improvement of growth and yield performance of brassica species under saline conditions. To mitigate the adverse effects of salinity, different strategies are required, among which application of osmolytes, especially inorganic osmolytes such as nitrogen and potassium are encouraging as they are efficient and economical. Siddique et al., [13], suggested that addition of nitrogen (N) can play a significant role in reducing the adverse effects of salt stress by the accumulation of osmoprotectants, availability of essential nutrients and photosynthetic capacity of plant. Jabeen and Ahmed [14], reported that the application of $\mathrm{KNO}_{3}$ improves growth and enzymatic activity (NRA), reduced increasing tendency of $\mathrm{Na}^{+}$and $\mathrm{Cl}^{-}$and increased leaf area, fresh and dry weight per plant, $\mathrm{NO}_{3}{ }^{-}$and soluble protein concentration in safflower (Carthamus tinctorius L.) 
and sunflower (Helianthus annuus L.). They also reported that the improvement of these parameters is irrespective of the plant grown under non saline or saline conditions. Alleviatory effects of foliar nutrient application of $\mathrm{Ca}\left(\mathrm{NO}_{3}\right)_{2}$ and $\mathrm{KNO}_{3} @ 10 \mathrm{mM}$ at $40 \mathrm{mM}$ salinity level in strawberry were also reported by Yildirim et al., [15] who observed approximately $50 \%$ increase in plant root and shoot dry weight. The present study is therefore designed to improve the yield performance of Brassica juncea (cv: Agati sarheen) grown under saline environment by the application of suitable doses of $\mathrm{KNO}_{3}$.

\section{Material and Methods}

Gravel culture (net house) studies were conducted to improve the salt tolerance in Brassica species through foliar application of $\mathrm{K}$ and $\mathrm{N}$. The $\mathrm{KNO}_{3}$ was applied @ 30 and $60 \mathrm{mM}$ foliarly along with few drops of Triton $\mathrm{x} 100$ to confirm its absorption properly. Crop was irrigated by nutrient solution. Two treatments (control and $9.0 \mathrm{dSm}^{-1}$ $\mathrm{NaCl}$ ), were imposed after two weeks of germination. The salinity was imposed by $\mathrm{NaCl}$ salt applied with irrigation. The experiment was laid out according to randomized complete block design (RCBD with two replicates. Physiological observations were recorded after 2nd spray (at the time of flowering). Proline, Glycine betaine, Na, K and $\mathrm{Cl}$ were determine in green leaves after extracting in $(0.5 \%)$ toulene water, according to Weimberg et al., [16]. Proline was estimated according to the method of Bates et al., [17]. Glycine-betaine was estimated according to Grieve and Gratan, [18]. Sodium $\left(\mathrm{Na}^{+}\right)$and Potassium $\left(\mathrm{K}^{+}\right)$ contents were measured in toluene extract by flame photometer after making suitable dilution with D.W. and nitrogen was determined by Kjeldhal method according to the standard methods as reported by Jackson [19].

Growth observations were recorded at the time of crop harvest in terms of plant height $(\mathrm{cm})$, slique length $(\mathrm{cm})$, grain weight $/ 5$ slique $(\mathrm{g})$ and grain yield / 15 plants (g). The data regarding all the growth parameters and biochemical aspects were analyzed statistically for analysis of variance (ANOVA) and Duncan Multiple Range Test (DMRT) using MSTAT-C computer package.

\section{Results}

\section{Growth Performance}

The decrease in plant height was approximately $30 \%$ under salinity. There was a gradual increase in plant height under normal condition with the increasing dose of $\mathrm{K}$ and $\mathrm{N}$ application i.e. less at $30 \mathrm{mM}$ and more at $60 \mathrm{mM} \mathrm{KNO}_{3}$. Under saline condition the response of $\mathrm{KNO}_{3} @ 30 \mathrm{mM}$ (T1) was better than $\mathrm{KNO}_{3} @ 60 \mathrm{mM}$ (T2), where maximum plant height was observed. However, the relative decrease was bit high under $\mathrm{T} 1(29.44 \%)$ than at $\mathrm{T} 2((28.0 \%)$ treatment.
The response of $\mathrm{KNO}_{3}$ was also better in case of slique length. There was a gradual increase in slique length with increasing dose of $\mathrm{KNO}_{3}$ i.e. more under $(\mathrm{T} 2=60 \mathrm{mM}$ $\left.\mathrm{KNO}_{3}\right)$ than $\left(\mathrm{T} 1=30 \mathrm{mM} \mathrm{KNO}{ }_{3}\right)$ treatment. The relative decrease was also less under $\mathrm{T} 2$ treatment (i.e. only $12.65 \%$ decrease).

The application of $\mathrm{KNO}_{3}$ did not show any significant effect in improving the grain weight / 5 slique of brassica genotype i.e. grain weight/ 5 slique was bit higher under T0 (DW) treatments (both under normal and saline soil condition as well). However the relative decrease under salinity was less both under $\mathrm{T} 1$ and $\mathrm{T} 2$ treatments. The values for relative decrease under $\mathrm{T} 1$ and $\mathrm{T} 2$ treatments were recorded as 28.57 and $28.87 \%$, respectively.

The application of $\mathrm{KNO}_{3}$ was also found to improve the grain yield of brassica, both under normal and saline conditions as well. Under saline condition the values for the grain yield were comparatively high under $\mathrm{T} 1$ treatment i.e. $\mathrm{KNO}_{3} @ 30 \mathrm{mM}$ then $\mathrm{T} 2$ treatment $\left(\mathrm{KNO}_{3} @ 60 \mathrm{mM}\right)$. The mean reduction was also less under lower dose of $\mathrm{KNO}_{3}$. i.e. $76 \%$ as compared to $\mathrm{T} 0$ (79.57) and $\mathrm{T} 2(80.75)$ treatments.

\section{Solute Accumulation}

Proline accumulation under normal soil condition was comparatively less, but its accumulation increased significantly in all the treatments under salinity (Figure 1a). Maximum increase was observed in T0 treatment followed by $\mathrm{T} 1$ and $\mathrm{T} 2$ treatments. Application of $\mathrm{KNO}_{3} @ 30 \mathrm{mM}$ (T1) improved the accumulation of proline plant under salinity. The relative increase in $\mathrm{T} 1$ treatment was maximum i.e. $86.54 \%$.

The trend in the accumulation of glycine betaine was also similar, where significant increase was observed under salinity (Figure 1b). However it varies among the treatments. Under normal soil condition maximum accumulation of proline was observed under $\mathrm{T} 0$ followed by $\mathrm{T} 1\left(\mathrm{KNO}_{3} @ 30 \mathrm{mM}\right.$.) and $\mathrm{T} 2\left(\mathrm{KNO}_{3} @ 60 \mathrm{mM}\right.$.), treatments. Under saline condition application of $\mathrm{N}$ and $\mathrm{K}$ at @ 30mM (T1) was found more effective to improve the accumulation of glycine betaine with maximum values of $53.15 \mu$ mole g $^{-1} \mathrm{~F}$.wt. The relative increase in $\mathrm{T} 1$ treatment was also maximum i.e. $31.58 \%$ followed by $15.18 \%$ in $\mathrm{T} 2$ treatment.

For better growth of plant under salinity, restricted uptake of $\mathrm{Na}$ ions is necessary. There was increase in $\mathrm{Na}$ uptake by brassica genotype under salinity ((Figure 1c). Under normal soil conditions the values for sodium accumulation were almost same under all the three treatments. Under saline conditions quite encouraging response of $\mathrm{N}$ and $\mathrm{K}$ application was observed in $\mathrm{T} 1$ treatment. Sodium uptake under T1 treatment was minimum i.e. $0.44 \%$. The relative increase in $\mathrm{T} 1$ treatment was also less i.e. $54 \%$. On the other hand no response was observed under $\mathrm{T} 2$ treatment, where the values for $\mathrm{Na}$ uptake were similar to $\mathrm{T} 0$ treatment i.e. $0.52 \%$ having $58 \%$ 
increased as compared to non-saline condition.

Proper regulation of potassium is also necessary for normal growth of plant under salinity. There was a significant decrease in $\mathrm{K}$ uptake due to increase in $\mathrm{Na}$ accumulation under salinity (Figure 1d). Application of K and $\mathrm{N}$ proved to increase the uptake of $\mathrm{K}$ in plants. Comparatively higher $\mathrm{K}$ accumulation was observed in $\mathrm{T} 1$ and $\mathrm{T} 2$ treatments under both growing environments (i.e. non-saline and saline).

Increased $\mathrm{Na}$ accumulation and decreased $\mathrm{K}$ uptake under salinity resulted in the decrease in $\mathrm{K} / \mathrm{Na}$ ratio in plant leaves (Figure 1e). K/Na ratio under normal conditions was higher ranging as $1.95-2.75$. Significant decrease was observed in all the treatments under saline environments. The $\mathrm{K} / \mathrm{Na}$ ratio was comparatively more under $\mathrm{T} 1$ followed by $\mathrm{T} 2$. The $\mathrm{K} / \mathrm{Na}$ ration under salinity in $\mathrm{T} 1$ and $\mathrm{T} 2$ was recorded as 0.61 and 0.56 , respectively. It was also observed that though the values of $\mathrm{K} / \mathrm{Na}$ ratio in $\mathrm{T} 1$ were the maximum but the relative decrease in $\mathrm{T} 2$ was comparatively less. i.e. $74 \%$.

Foliar application of $\mathrm{N}$ containing salt (i.e. $\mathrm{KNO}_{3}$ ) did not showed any significant increase in $\mathrm{N}$ under normal soil conditions (Fig.1f). However, under saline conditions the response was quite encouraging. Here again the response of low $\mathrm{KNO}_{3}$ dose (T1) was comparatively better than the higher one (i.e. T2). Total nitrogen under T1 was maximum $(4.96 \%)$ followed by T2 $(4.22 \%)$. The relative decrease under T1 and $\mathrm{T} 2$ was also minimum i.e. 10.66 and $20.76 \%$, respectively.

\section{Discussions}

Nitrogen and potassium play a vital role in plant growth. The availability of these major nutrients depressed under salinity environment. According to Pooja and Kumar [20], ion toxicity and imbalanced nutrition in saline conditions are the main constraints for plant growth. It is reported that in saline conditions, nutrient imbalances can result through various ways: From the effect of salinity on nutrient availability, competitive uptake, transport or partitioning within the plant or may be caused by physiological inactivation of a given nutrient (such as $\mathrm{K}$ ) resulting in an increase in the plant's internal requirement for that essential element (Ashraf, [21]. Under saline/ drought conditions, foliar application of nutrients to stressed wheat might offer a way to alleviate these stresses (Schmidhadhalter et al, [22]). In the present studies significant effects of salinity were observed on growth (plant height, slique length) and grain yield in brassica. Foliar supplementation of nitrogen and potassium resulted in improved plant growth under salinity. Under saline condition the response of $\mathrm{KNO}_{3} @$ $30 \mathrm{mM}$ was better than @ 60mM. The values for the grain yield were comparatively high under (T1) treatment. This might be due to the provision of nutrients in adequate amount at a stage with maximum of their demand. Positive results of daily application of $\mathrm{N} \& \mathrm{~K}$ were observed by Day et al., [23]; Rengel and Marschner, [24] in salt or drought stressed maiz and wheat.

Increased photosynthetic material also resulted in higher values of grain yield of Brassica under $\mathrm{KNO}_{3} @ 30 \mathrm{mM}$ treatment. Siddique [13] reported that increased activity rubisco (a key enzyme for fixation of $\mathrm{CO}_{2}$ ) may be responsible for higher utilization of leaf nitrogen. Further the higher portion of leaf $-\mathrm{N}$ in chloroplast, mostly invested in rubisco alone.

Accumulation of organic (i.e. proline and glycine betaine) and inorganic (sodium) solutes also increased in brassica plants due to salinity. (Marcum and Murdoch, [25]; Khan et al., [26] also observed increased proline and glycine betaine due to increasing salinity level. The accumulation of organic solutes is necessary to maintain the water potential equilibrium inside the cytosol (Tabatabaei and Fakhrzad, [27]. In the present studies there was an overall increase in proline irrespect to $\mathrm{K}$ and $\mathrm{N}$ application; while the accumulation of glycine betaine under $\mathrm{KNO}_{3}$ treatments was encouraging. The accumulation of GB plant leaves in response to water and salt stress are also reported by Khafagy et al. [28]. They observed that pre-treatment with glycine betaine or ascorbic acid mitigates the effect of salinity on thickness of the midrib region and mesophyll tissue of leaf blade. The increase in Nitrogen Containing Compounds (NCC) might be due to foliar absorption of $\mathrm{N}$ by plants, as there was higher accumulation of $\mathrm{N}$ in $\mathrm{KNO}_{3}$ treatments as compared to control. Siddique et al., [13] reported that foliar application of $\mathrm{N}$ plays a vital role in the synthesis of Nitrogen Containing Compounds (NCC), which are beneficial for several enzymes activities in plants (Mansour, [29]). According to Siddique et al., [13], the efficiency of $\mathrm{N}$ in alleviating the adverse effect of salt stress in plants may be attributed to their ameliorative effect on the primary growth potential, activities of NR and $\mathrm{CA}$ enzymes, membrane permeability and N-use efficiency.

Under salinity there was increase in $\mathrm{Na}$ and decrease in $\mathrm{K}$ in all the treated plants. The alleviating effects of $\mathrm{KNO} 3$ were quite significant under $\mathrm{T} 1$ treated plants, showing bit lesser increase in Na accumulation. The results of present investigation are in agreement with the findings of many workers in different plant species (Abdel-Rehman, [30]; Cha-um et al., [31]; Sultana et al., [32]; Tabatabaei and Fakhrzad, [27] who observed better absorption of $\mathrm{K}$ in shoot when applied to foliage directly. This shows that under saline condition application of $\mathrm{K}$ in combination with $\mathrm{N}$ may be quite helpful in mitigating the toxic effects of sodium. It is therefore recommended that for better growth and yield response of brassica genotypes may be supplemented @ $30 \mathrm{mM}$ or $60 \mathrm{mM} \mathrm{KNO}_{3}$ 
(Brassica juncea, cv: Agati sarheen)

Table 1. Effect of $\mathrm{N}$ and $\mathrm{K}$ growth performance of Brassica genotype (cv: Agati sarheen)

\begin{tabular}{|c|c|c|c|}
\hline Treatments & Non saline & Saline & Rel. dec. (\%) \\
\hline & \multicolumn{3}{|c|}{ plant height (cm) } \\
\hline T0 (Distilled Water) & $144 \mathrm{a}$ & $95 \mathrm{~b}$ & 33.91 \\
\hline $\mathrm{T} 1\left(\mathrm{KNO}_{3} @ 30 \mathrm{mM}\right)$ & $151 \mathrm{a}$ & $107 \mathrm{~b}$ & 29.44 \\
\hline T2 $\left(\mathrm{KNO}_{3} @ 60 \mathrm{mM}\right)$ & $142 \mathrm{a}$ & $102 \mathrm{~b}$ & 28.09 \\
\hline \multicolumn{2}{|c|}{$\operatorname{LSD}(0.05)=4.047$} & & \\
\hline & \multicolumn{3}{|c|}{ Slique length (cm) } \\
\hline T0 (Distilled Water) & 4.11 & 3.33 & 18.98 \\
\hline $\mathrm{T} 1\left(\mathrm{KNO}_{3} @ 30 \mathrm{mM}\right)$ & 4.14 & 3.43 & 17.15 \\
\hline T2 $\left(\mathrm{KNO}_{3} @ 60 \mathrm{mM}\right)$ & 4.11 & 3.59 & 12.65 \\
\hline \multicolumn{4}{|c|}{ NS } \\
\hline & \multicolumn{3}{|c|}{ Grains weight/ 5 slique (g) } \\
\hline T0 (Distilled Water) & 0.156 & 0.109 & 30.13 \\
\hline $\mathrm{T} 1\left(\mathrm{KNO}_{3} @ 30 \mathrm{mM}\right)$ & 0.147 & 0.105 & 28.57 \\
\hline T2 $\left(\mathrm{KNO}_{3} @ 60 \mathrm{mM}\right)$ & 0.142 & 0.101 & 28.87 \\
\hline \multicolumn{4}{|c|}{ NS } \\
\hline & \multicolumn{3}{|c|}{ Grain yield row ${ }^{-1}$ (15 plants) } \\
\hline T0 (Distilled Water) & $23.0 \mathrm{c}$ & $4.70 \mathrm{f}$ & 79.57 \\
\hline T1 ( $\left.\mathrm{KNO}_{3} @ 30 \mathrm{mM}\right)$ & $32.6 \mathrm{~b}$ & $7.60 \mathrm{~d}$ & 76.69 \\
\hline $\mathrm{T} 2\left(\mathrm{KNO}_{3} @ 60 \mathrm{mM}\right)$ & $37.4 \mathrm{a}$ & $7.20 \mathrm{e}$ & 80.75 \\
\hline \multicolumn{2}{|c|}{$\operatorname{LSD}(0.05)=0.0813$} & & \\
\hline
\end{tabular}



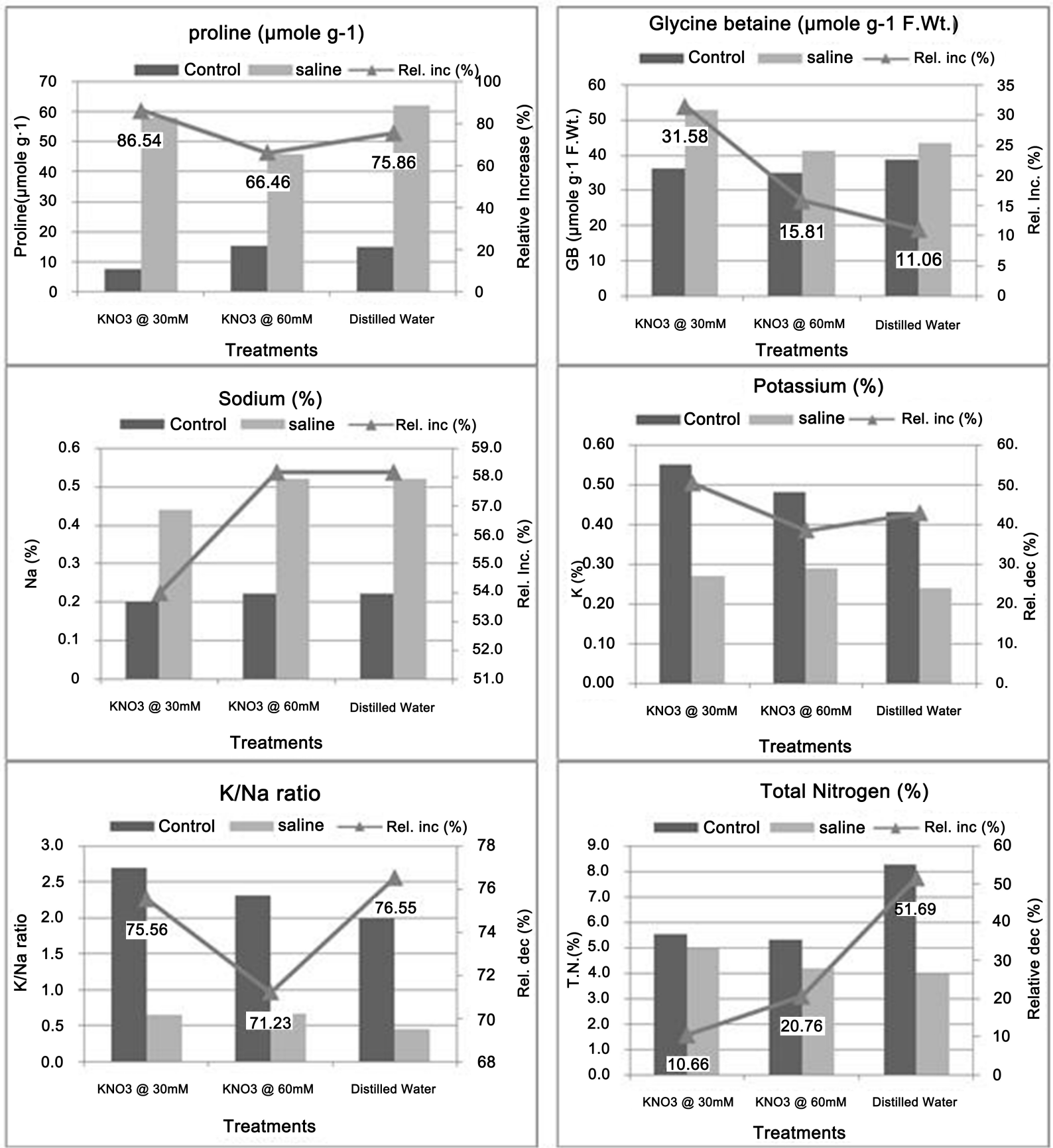

Figure 1. Effect of $\mathrm{N}$ and $\mathrm{K}$ application on solute (organic and inorganic) accumulation in brassica genotype (cv: Agati sarheen)

\section{REFERENCES}

[1] Khan, G.S. 1998. Soil salinity/sodicity status in Pakistan. Soil Survey of Pakistan, Lahore. pp: 19.

[2] Khan, M. A., M.U. Shirazi, Mukhtiar Ali, S. Mumtaz, A. Sherin and M. Y. Ashraf. 2006. Comparative performance of some wheat genotypes growing under saline water. Pak. J. Bot., 38(5): 1633-1639.

[3] Shirazi, M.U., M.A. Khan, B. Khanzada, S.M. Mujtaba, Mukhtiar Ali, Muhammad Ali, Saba Mumtaz, Aisha

Shereen, Aqil Siddique and J. A. Shah. 2007. Salt tolerance studies in some mutants of brassica (brassica juncea, cv: s9).Pak. J. Bot., 39(7): 2495-2500, 2007.

[4] Govt. Of Pakistan 2001. Agricultural Statistics of Pakistan. Govt. of Pakistan, Ministry of Food and Agriculture, Islamabad.

[5] Maas E.V. and G. J. Hoffman. 1977. Crop salt tolerance: Current assessment. J. Irrig. Drainage Div., Am. Soc. Civ. Eng. 103:115-134.

[6] Puppala, N. J., L. Fowler, L. Poindexter and H. L. Bhadwaj 1999. Evaluation of salinity tolerance of canola germination, In Perspectives on new crops and new uses. Janick J., Ed.; ASHS press, Alexandria, VA. 251-253. 
[7] Mer, R.K., P. K. Prajith, D. H. Pandya, and A. N. Pandey 2000. Effect of salts on germination of seeds and growth of young plants of Hordeum vulgare, Triticum aestivum, Cicer arietinum and B. juncea. J. of Agron and Crop Sci., 185: 209-217.

[8] Baybordi, A. 2010. The Influence of Salt Stress on Seed Germination, Growth and Yield of Canola Cultivars, Not. Bot. Hort. Agrobot. Cluj. 38 (1): 128-133.

[9] Tunuturk, M., R. Tuncturk, B. Yildirim and V. Ciftci. 2011. Effect of salinity stress on plant fresh weight and nutrient composition of some canola (B. napus L.) cultivars. Afr. J. Biotech., 10(10): 1827-1832.

[10] Zamani, S., M.T. Nezami, D. Habibi and M. B. Khorshidi. 2010. Effect of quantitative and qualitative performance of four canola cultivars (B. napus L) t salinity conditions. Adv. Environ. Bio. 4(3): 422-427.

[11] Mass, E.V. 1990.Crop salt tolerance. In: ASCE manuals and reports on engineering K. K. Tanji (ed), pp: 262-304. New York.

[12] Ashraf, A., and T. McNchilly, 2004. Salinity Tolerance in Brassica Oilseeds. In: Critical Reviews in Plant Sciences 23 (2): 157-174.

[13] Siddiqui, M. H., F. Mohammad, M N. Khan, M.H Al-Whaibi and A.H. A. Bahkali. 2010. Nitrogen in Relation to Photosynthetic Capacity and Accumulation of Osmoprotectant and Nutrients in Brassica Genotypes Grown Under Salt Stress. Science Direct, 9(5): 671-680.

[14] Jabeen N. and Ahmad R. 2011. Foliar Application of Potassium Nitrate Affects the Growth and Nitrate Reductase Activity in Sunflower and Safflower Leaves under SalinityNot Bot Horti Agrobo, 2011, 39(2):172-178.

[15] Yildirim, E., H. Karlidag and M. Turan. 2009. Mitigation of salt stress in strawberry by foliar $\mathrm{K}, \mathrm{Ca}$ and $\mathrm{Mg}$ nutrient supply. Plant Soil Environ. 55, (5): 213-221.

[16] Weimberg, R, H.R. Lerner and A. Poljakoff-Mayber. 1981. Kinetics of Toluene-induced leakage of low molecular weight solutes from excised sorghum tissues. Plant Physiol., 68: $1433-1438$.

[17] Bates, L.S., R.P. Waldren and I.D. Tears. 1973. Rapid determination of free proline for water stress studies. Plant and Soil, 39: 205-207.

[18] Grieve C.M. and S.R. Gratan. 1983. Rapid assay for determination of water soluble. Quaternary ammonium compounds. Plant and Soil, 70: 303-307.

[19] Jackson, M.L. 1958. Soil Chemical Analysis. Prentice Hall, Constable and Company Ltd. London. W.C. 2

[20] Pooja S., and R. Kumar, 2015. Soil salinity: A serious environmental issue and plant growth promoting bacteria as one of the tools for its alleviation. Saudi Journal of Biological Sciences (2015) 22, 123-131.

[21] Ashraf, M., 2004. Some important physiological selection criteria for salt tolerance in plants. Flora 199, 361-376.

[22] Schmidhadhalter, U., Z. Burucs, S. von Tucher, Y. Hu and R. Guteer. 1999. Foliar Fertilization, applied to droughted and salinized wheat and Maiz seedlings. In: procceding of 2nd Int. Workshop on Foliar Fertilization, April 4-10, 1999, Bangkok, Thailand, 343-358.

[23] Day, K.J., M.J. Hutchings and E.A. John. 2003. The effects of spatial pattern of nutrient supply on yield, structure and mortality in plant populations. J. Ecol., 91: 541-553.

[24] Rengel Z and Marschner P 2005 Nutrient availability and management in the rhizosphere: exploiting genotypic differences. New Phytologist 168, 305-312.

[25] Marcum, K.B. and C.L. Murdoch, 1994. Salinity tolerance mechanisms of sic C4 turfgrasses J. Amer. Soc. Hort. Sci., 119: 779-784.

[26] Khan M.A., M.U. Shirazi, Muhammad Ali Khan, S.M. Mujtaba, E. Islam, S. Mumtaz, A. Shereen, R.U. Ansari and M. .Y Ashraf. 2009. Role of proline, $\mathrm{K} / \mathrm{Na}$ ratio and chlorophyll content in salt tolerance of wheat (Triticum aestivum 1.) Pak. J. Bot., 41(2): 633-638.

[27] Tabatabaei SJ and F. Fakhrzad. 2008. Foliar and soil application of potassium nitrate affects the tolerance of salinity and canopy growth of perennial ryegrass (Lolium perenne var 'Boulevard'). Am J Agri Biol Sci 3 (3):544-550.

[28] Khafagy M. A, A. A. Arafa and M.F. El-Banna.2009 Glycine betaine and ascorbic acid can alleviate the harmful effects of $\mathrm{NaCl}$ salinity in sweet pepper. Australian Journal of Crop Science 3(5):257-267.

[29] Mansour 2000). Mansour, M. M. F. 1998. Protection of plasma membrane of onion epidermal cells by glycine betaine and proline against $\mathrm{NaCl}$ stress. Plant Physiol. Biochem., 36: 767-772.

[30] Abdel-Rahman AAM (1999). Productivity of some rice varieties as influence by different concentrations of foliar spray of urea under saline soil conditions. Egypt J Agric. Res $77: 242-251$

[31] Cha-um S, Siringam K, Juntawong N (2010). Water relations, pigment stabilization, photosynthetic abilities and growth improvement in salt stressed rice plant treated with exogenous potassium nitrate application. Int J Plant Prod 4(3):187-198.

[32] Sultana N, Ikeda T, Kashem MA (2001). Effect of foliar spray of nutrient solutions on photosynthesis, dry matter accumulation and yield in sea water-stressed rice. Environ Exp Bot 46:129-140. 